\title{
THE LEVEL OF OCCUPATIONAL AWARENESS AMONG THE TWELFTH GRADE STUDENTS AND THEIR PARENTS IN THE AL BATINAH REGION, SOUTH OF THE SULTANATE OF OMAN
}

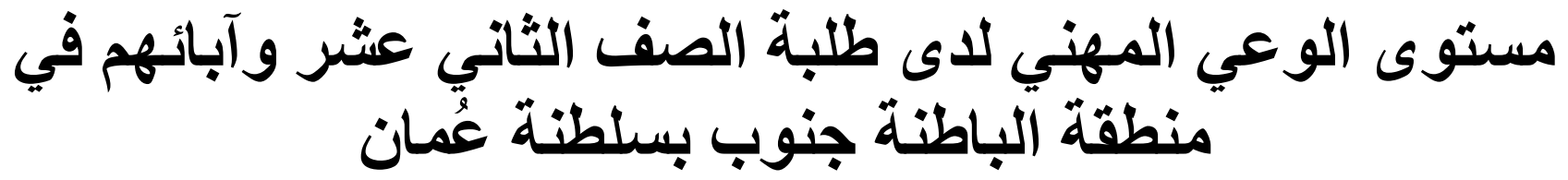

\author{
عادل بن محمد بن ناصر الكندي \\ Adil Mohammed Al-Kindi ${ }^{1 *}$, Dawood Abdulmalek Al-Hidabi ${ }^{2}$ and Ahmad Jumaa Al- \\ Riymi $^{3}$ \\ ${ }^{1}$ Ph.D. Candidate at the Faculty of Education, International Islamic University Malaysia (IIUM), \\ Adel.alkindi@moe.om \\ ${ }^{2}$ Prof. Dr. at the Kulliyyah of Education, International Islamic University Malaysia (IIUM); \\ Dawood@iium.edu.my \\ ${ }^{3}$ Prof. Dr. at the Rustaq College of Education, Oman, Ahmed.rus@cas.edu.om \\ * Corresponding author
}

\begin{abstract}
This quantitative study discussed the level of students' professional awareness. The problem arises from the presence of many factors that affect the student's professional choice, including the student's knowledge of himself and his capabilities and his ability to make a sound professional decision, and his knowledge of rehabilitation institutions, university education and the world of professions. Including what has to do with the surrounding environment, including parents and their professional awareness. So the aim of the study is: To know the level of occupational awareness among the twelfth-grade students and their parents in the Al Batinah region south of the Sultanate of Oman. And reveal the statistically significant differences in occupational awareness between the twelfth-grade students and their parents. Study methodology; I followed the descriptive analytical research methodology. The study population consisted of all 12th graders in the region. They are (6125) male and female students, distributed among (37) schools in six states. The sample consisted of (312) students. The number of males (152) and females (160). These students meet their parents (312). A unified scale for occupational awareness for students and parents was designed, it included (47) items distributed in six areas: the field of vocational guidance activities, the direction towards work, professional inclinations and capabilities, professional decision-making, professional attention, and vocational planning. Statistical treatment: Descriptive analysis, ( $\mathrm{T}$ ) test, and ANOVA (One-Way test) were used. The results showed that the level of students 'professional awareness is higher than the educationally acceptable average, as well as for their parents, and that the levels of students' professional awareness fields for parents are (6) All of them came above
\end{abstract}


the educationally acceptable average, and the results also showed that there were statistically significant differences in occupational awareness between students and their parents in favor of students.

Keywords: professional awareness, students, parents.

\section{الملـخــ}

ناقتشتْ هذه الدر اسة الكمية مستوى الوعي المهني لدى الطلبة. تبرز المشكلة بوجود كثير من العوامل

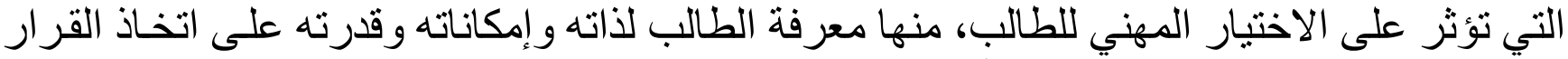

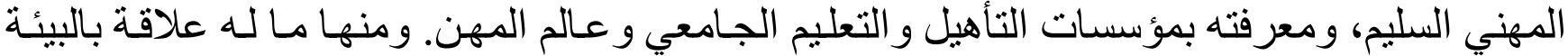

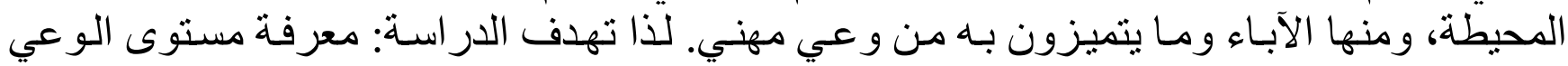

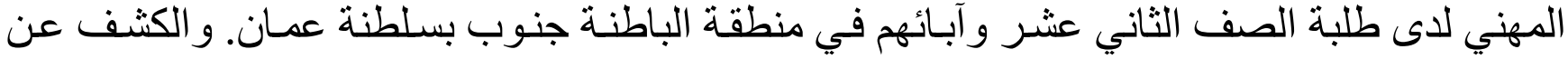

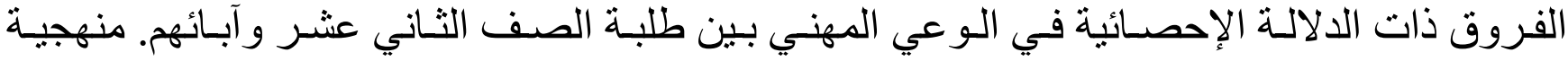

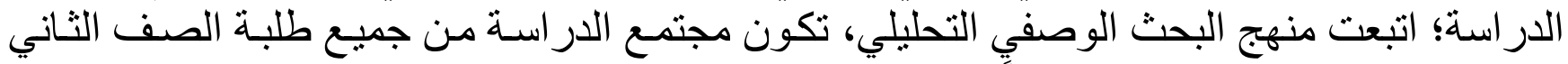

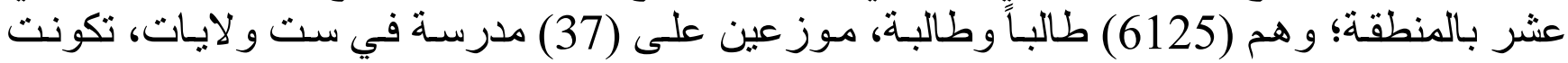

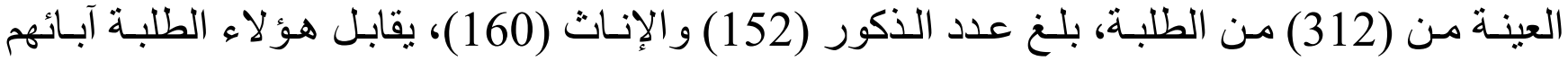

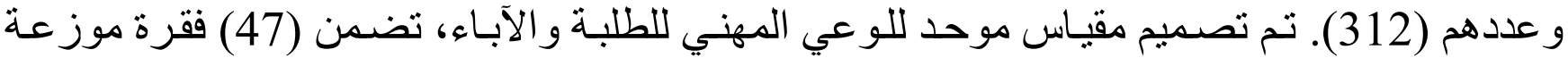

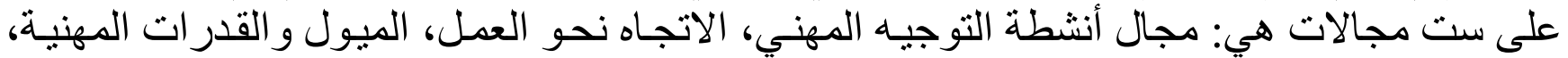

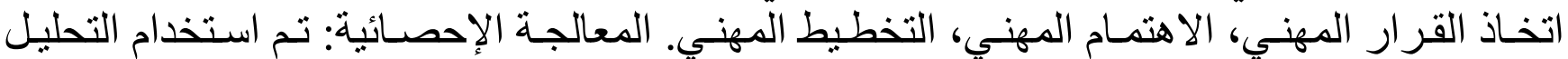

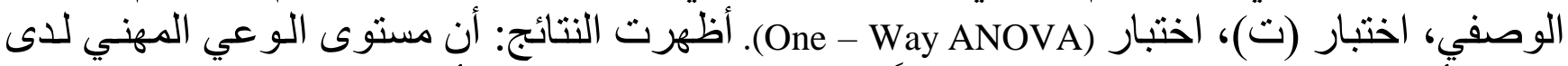

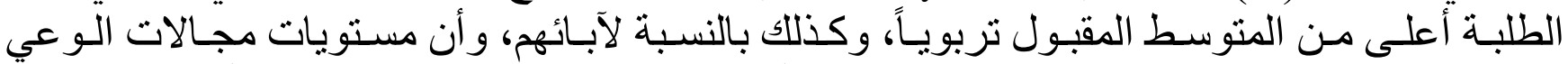

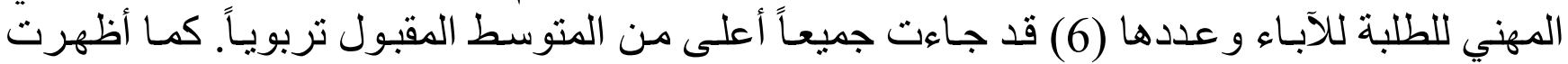
النتائج كذللك وجود فروق ذات دلالة إحصائية في الوعي المهني بين الطلبة وآبائهم لصالح الطيات الطلبة. كلمات مفتاحية: الوعي المهني، الطلبة، الآباء.

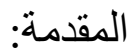

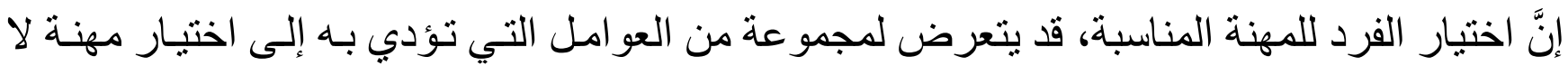

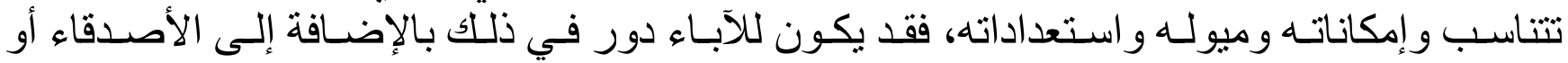

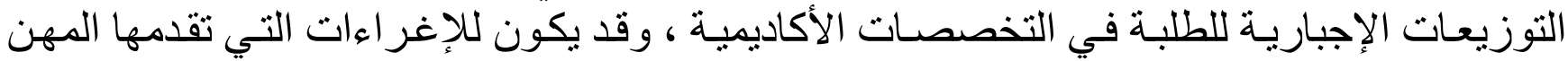

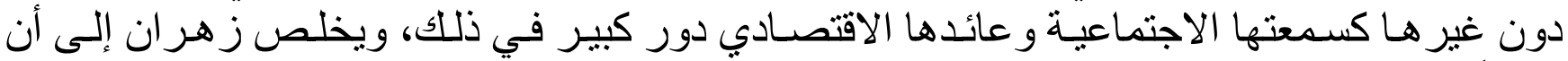

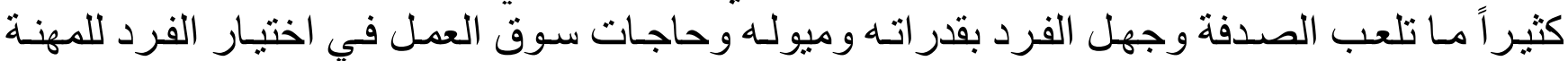

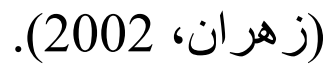

فو عي الإنسان بحاجته الأساسية و المتمثلة في تحقيق ذاته، والطرق و الوسـائل التي تشبعها عن طريق 
استغلال القدر ات والإمكانات التي يتمتع بها في أنشطة وأعمال مناسبة يعتبر أمر اً بـالغ الأهمية؛ نظر التها لارثباطه الوثيق بيناء المجتمع وتحقيق أهدافه وخططه التنموية.

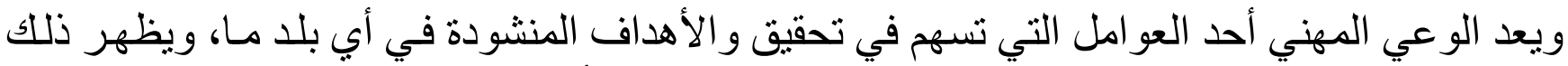

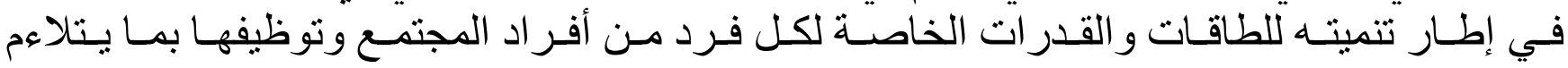
و الخصائص الجسمية و النفسية و الاجنماعية التي يتمتع بها.

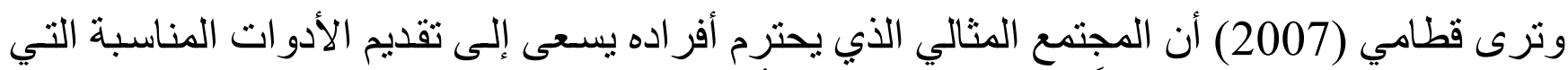

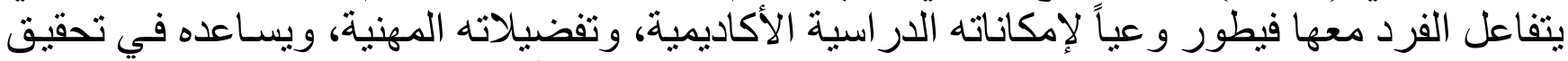

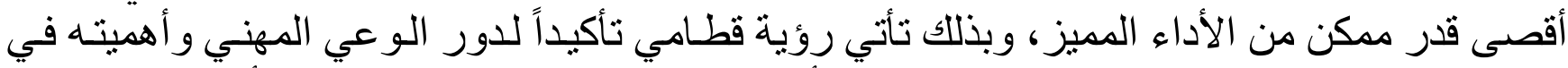

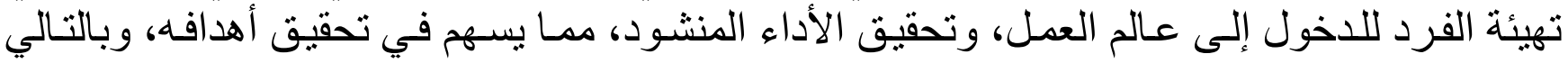

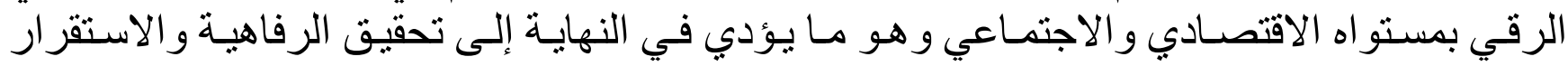
لمنمتع.

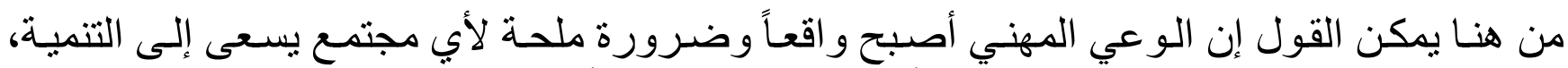

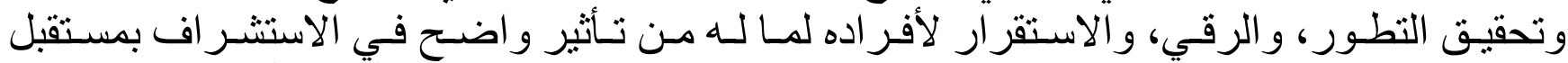

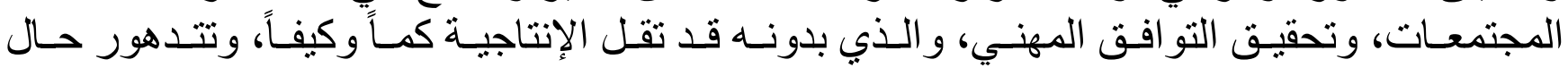

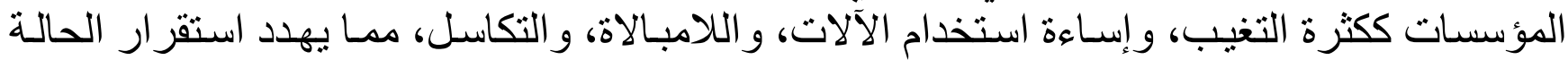
الاقتصادية لها (ملحم، 2007).

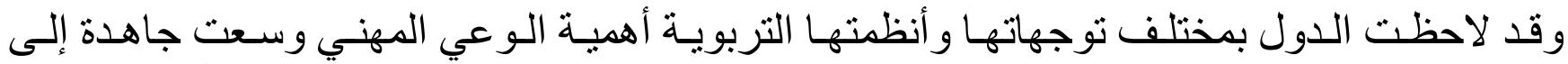

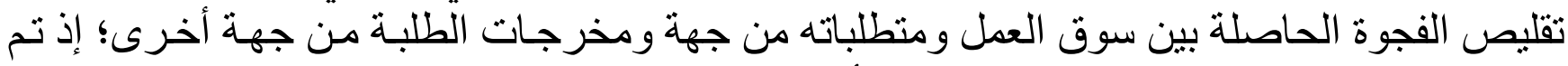

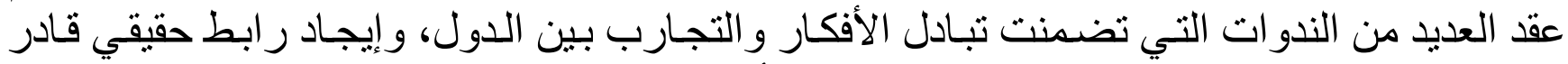

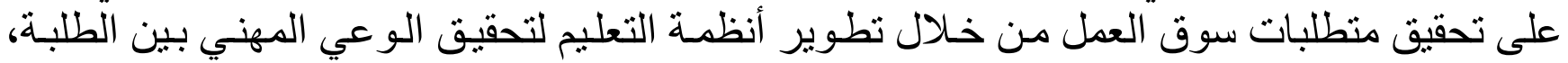

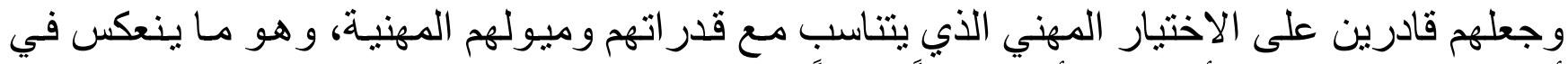

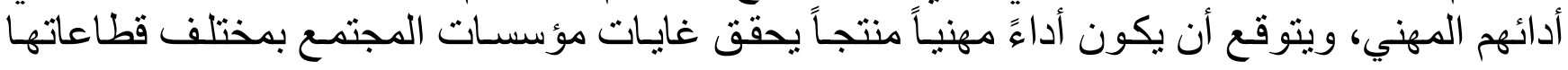

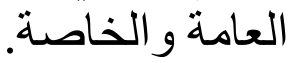

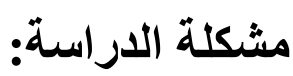

تأتي أهميـة تنميـة الوعي المهني لدى طلبـة التعليم الأساسـي ومـا بعده لتتناسب و الاتجاهـات العالميـة

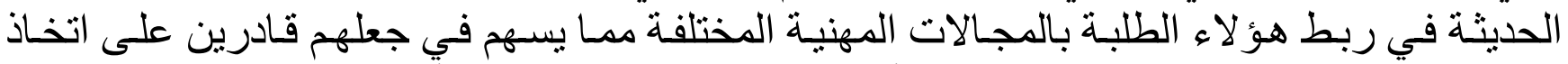

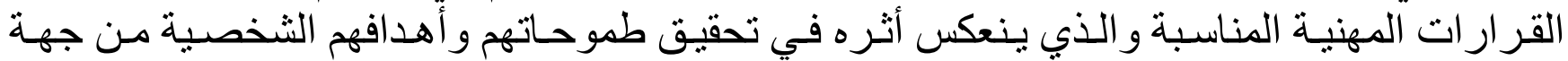
وأهداف المجتمع من جهة أخرى.

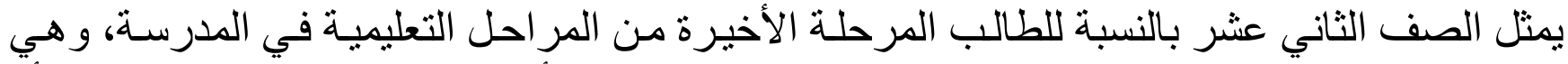

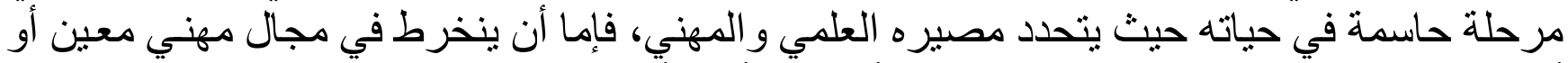

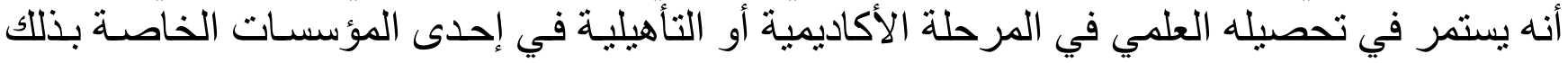
كالمعاهد، و المر اكز العلمية، و الجامعات و الكليات (الحكومية منها والخهية الخاصة). 
وباعتبار الصف الثاني عثر بالنسبة للطالب هي المرحلة الأخيرة و الحاسمة من المر احل الدر اسية في

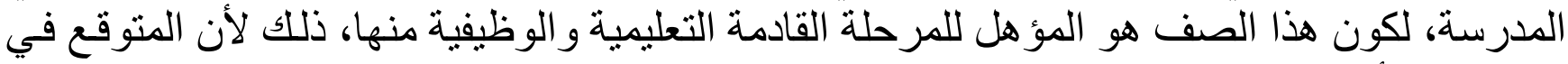
هذا الصف أن يكون الطالب قد وصل إلى مرحلة جيدة مـن الوعي المهني، فقد مر بمر احل عديدة،

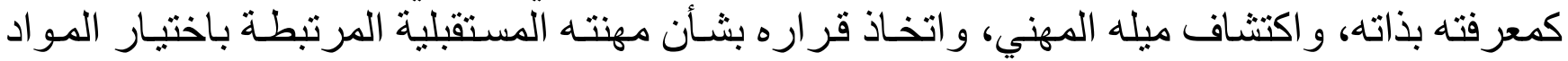

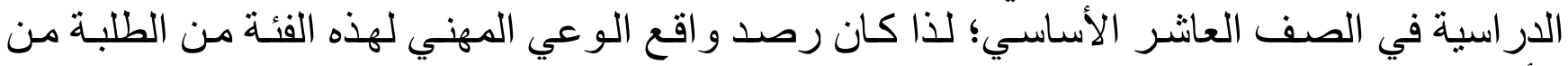

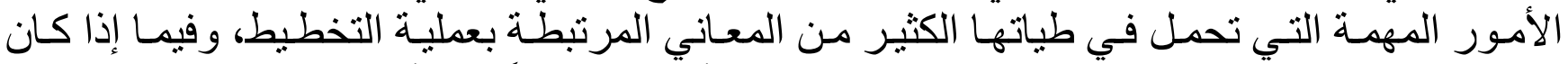
اختيار الطلبة للمو اد الدر اسية ألمرتبطة بالتخصصات الأكاديمية مبنياً على أسس علمية علية ووعي مهني.

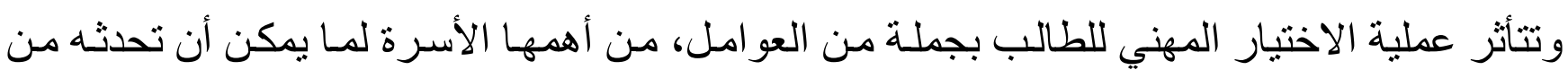

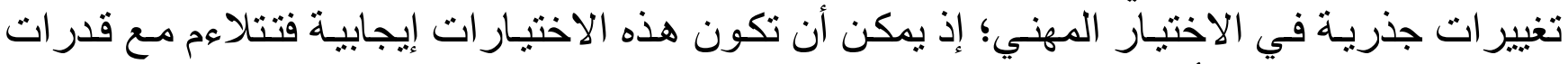

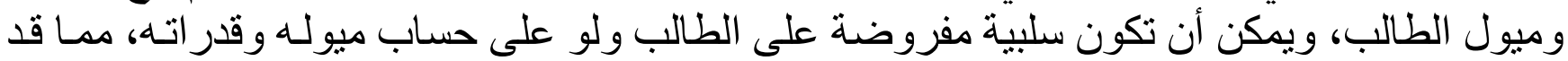

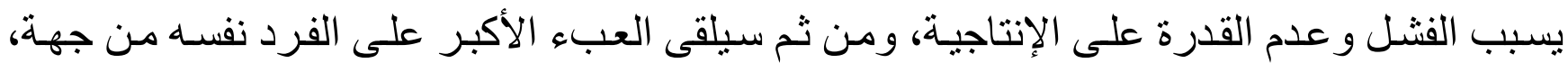
و وعلى المجتمع ومؤسساته من جهة أخرى الفئ

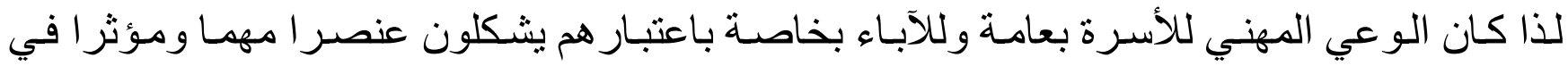

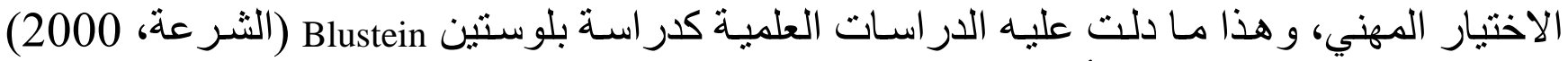

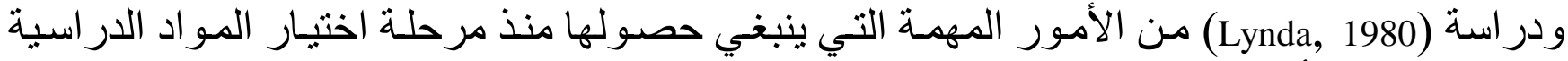

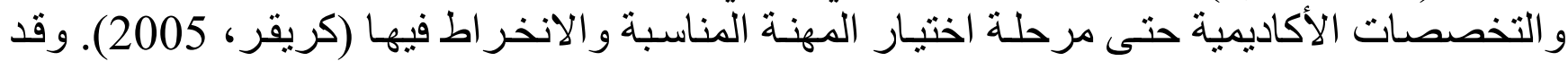

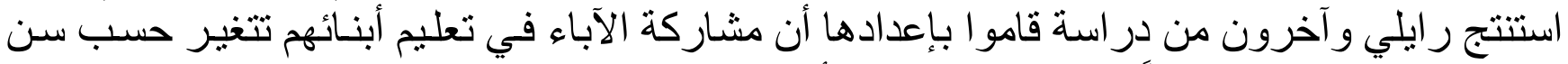

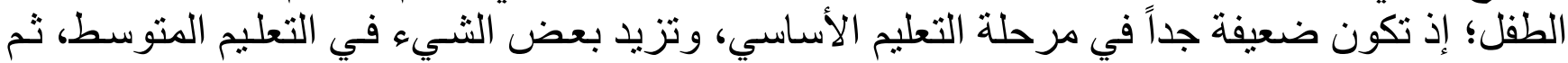

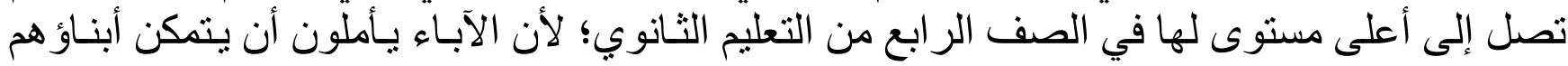
من الالتحاق إلى المكان المفضل لهم (الحارثية، 2002).

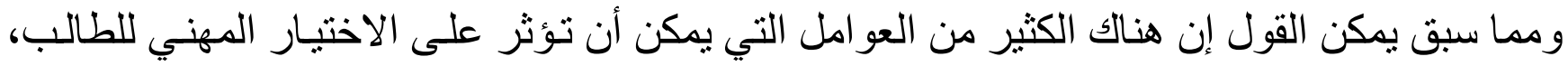

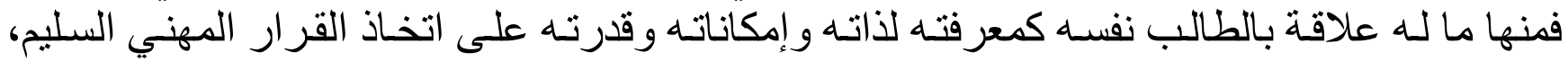

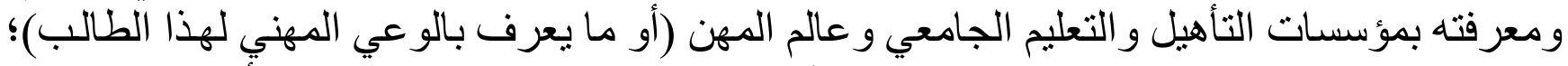

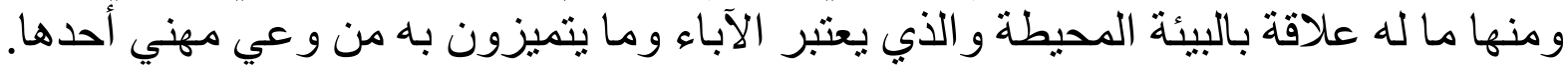

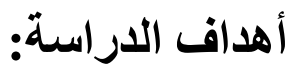

أ. تنخيص مسنوى الوعي المهني لدى طلبة الصف الثاني عثر في منطقة الباطنة جنوب بسلطنة عُمان.

ب.تشخيص مستوى الوعي المهني لدى آباء الطلبة في منطقة الباطنة جنوب بسلطنة عُمان. تـ الكثـف عن الفـروق ذات الدلالـة الإحصـائية في الـوعي المهني بـين طلبـة الصـف الثـاني عثـر و آبائهر.

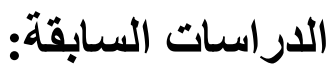




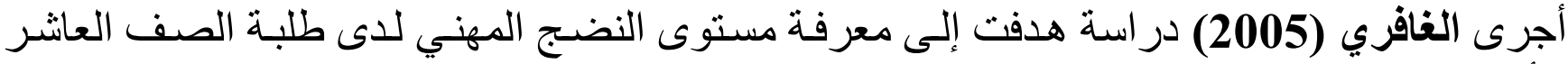

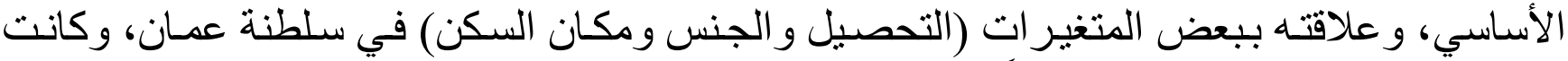

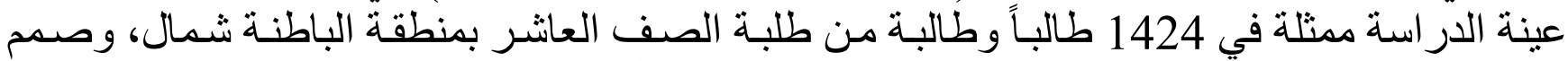

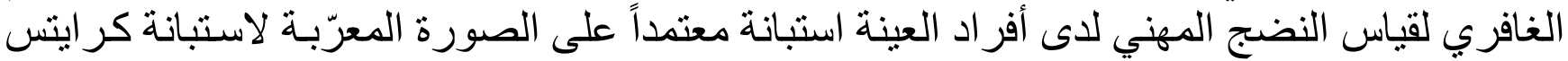

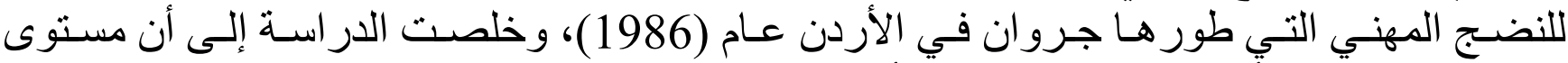

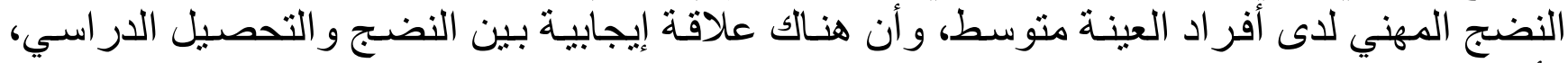

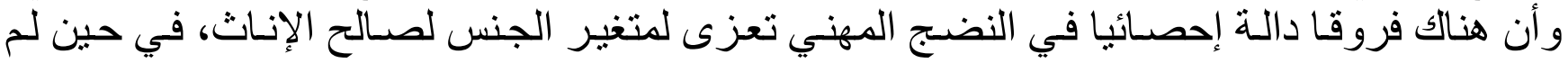
تظهر هذه الفروق بين طلبة القرية وطلبة المدينة.

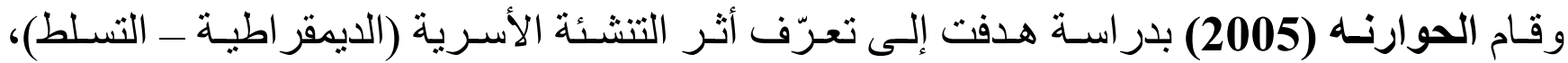

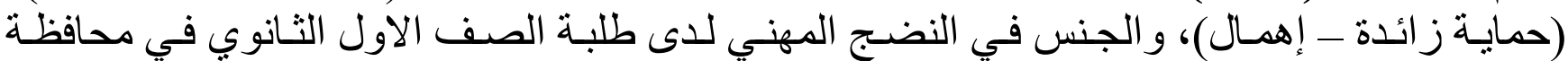

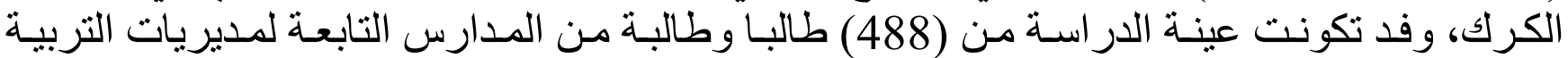

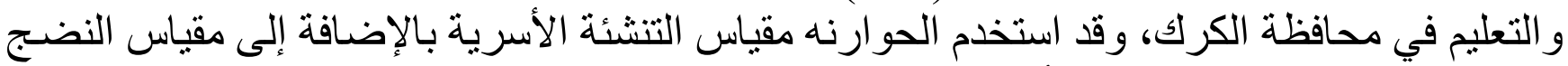

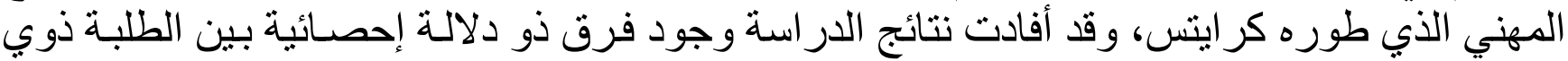

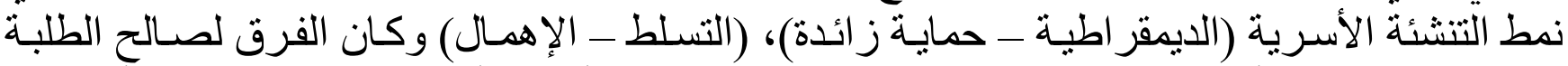

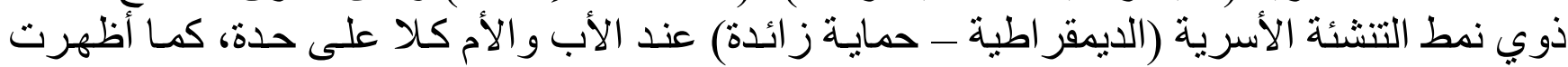

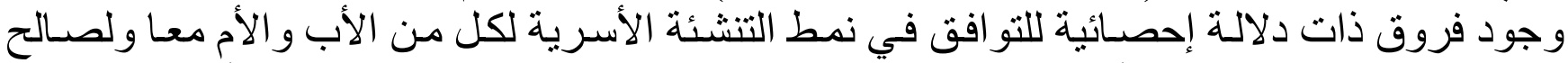

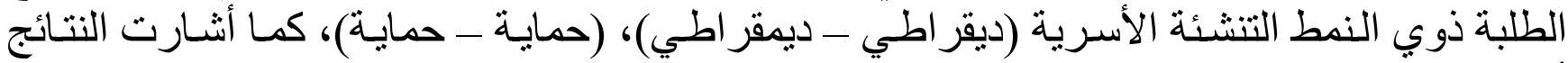
أيضا إلى عدم وجود فروق ذات دلالة إحصائية لمستوى النضج المهني تعزى لجنس الطالب.

قامـت جاتيــ (Janet,2005) بدر اســة هـدفت إلـى تعـرّف المفــاهيم العامـة فيمـا يخـص المسـتقبل

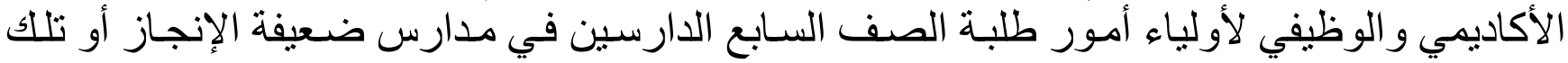

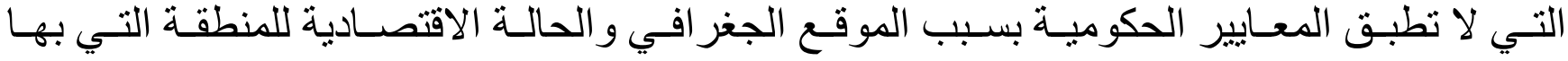

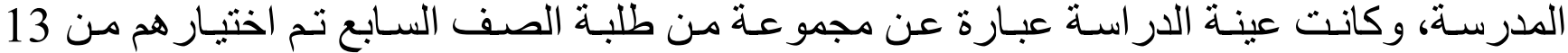

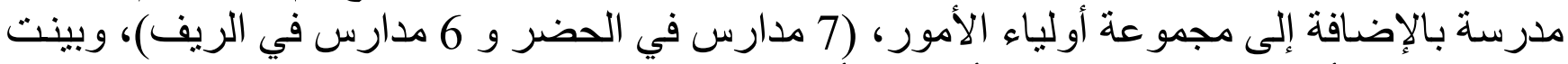

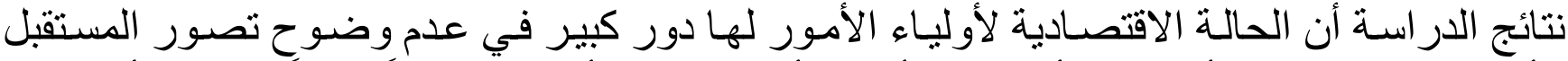

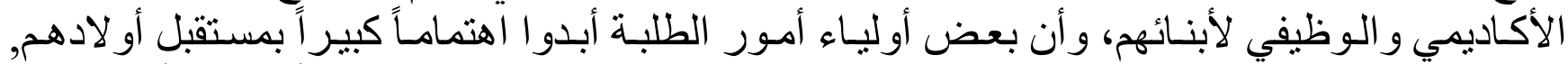

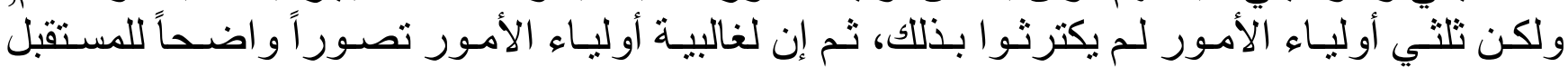
الأكاديمي و الوظيفي لأبنائهم ولكنهم كانو ا يشعرون بالذنب بسبب طبيعة الوظيفة التي هم يمارسونها

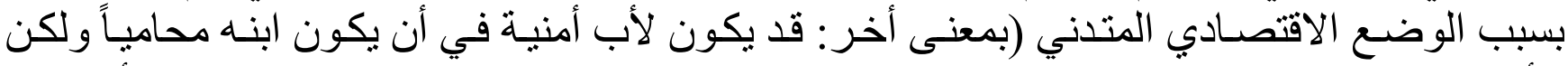

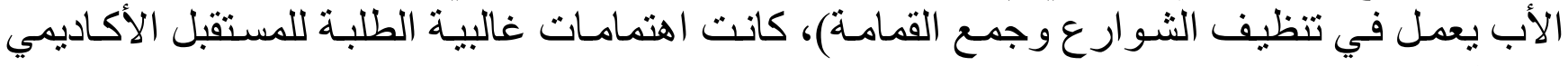

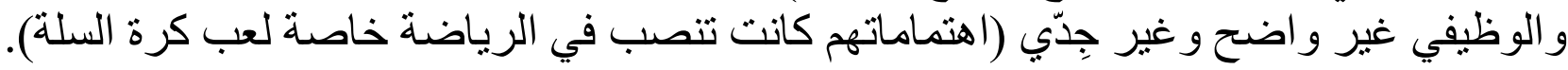
منهجية الدراسة: تتبع هذه الدر اسة منهج البحث الوصفي التحليلي، مجتمع الدر اسـة: تكون من جميع طلبـة الصف الثناني عشر بالمنطقة؛ وهـ (6125) طالبـاً وطالبـة، 
موز عين على (37) مدرسة في ست و لايات، عينة الدر اسة: نكونت العينة من (312) من الطلبة، بلـغ عدد الذكور (152) والإنـاث (160)، يقابل هؤ لاء الطلبة آبائهم و عددهم (312). مقياس الدر اسة: تم تصميم مقياس موحد للوعي المهني للطلبة والآباء، تضمن (47) فقرة موزعة على التى الته

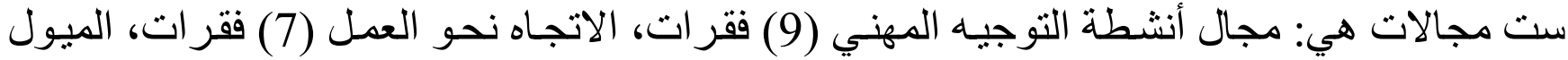

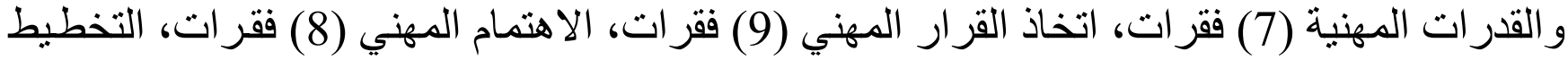
المهني (7) فقرات المن.

المعالجة الإحصائية: تم استخدام التحليل الوصفي، اختبار (ت)، اختبار (One - Way ANOVA). نتائج الاراسة: النتائج المتعلقة بالسؤال الأول: ما مستوى الوعي المهني لاى طلبة الصف الثاني عشر؟ مستوى الوعي المهني لطلبة الصف الثاني عشر في الأداة ككل:

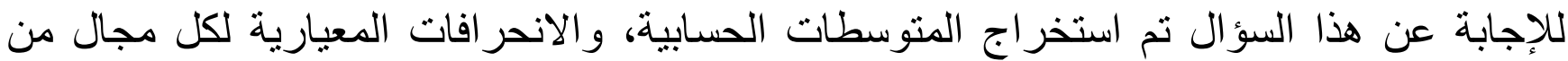

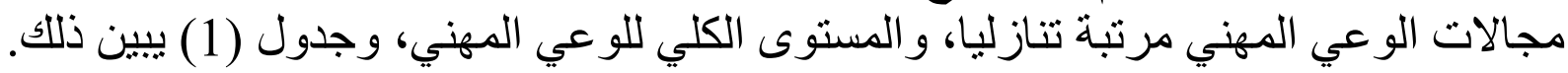
جدول (1) المتوسطات الحسابية والانحر افات المعيارية لجميع مجالات الوعي المهني مرنبة تنازليا

\begin{tabular}{|c|c|c|c|}
\hline الاتحراف المعياري & الحستابي & مجالات الوعي المهني & p \\
\hline 0.410 & 4.26 & الاهتمـــام المهني & 1 \\
\hline 0.500 & 4.05 & الاتجــاه نحو العمل & 2 \\
\hline 0.419 & 4.02 & التخــطيط المــني & 3 \\
\hline 0.381 & 3.70 & تحديد الميول و القدر ات المهنية & 4 \\
\hline 0.495 & 3.63 & أنشطة الـتوجيه المهني & 5 \\
\hline 0.436 & 3.62 & اتخــاذ الـقر ار المهني & 6 \\
\hline 0.257 & 3.88 & 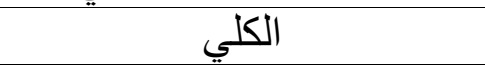 & \\
\hline
\end{tabular}

يبين جدول (1) أن مجال "الاهتمام المهني" جاء في المرتبة الأولى بأعلى متوسط حسابي بلغ

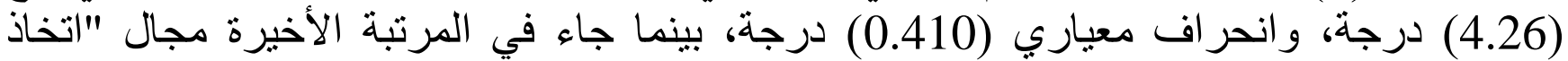

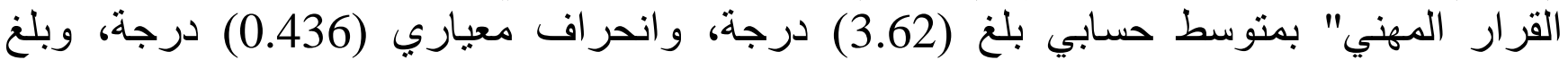

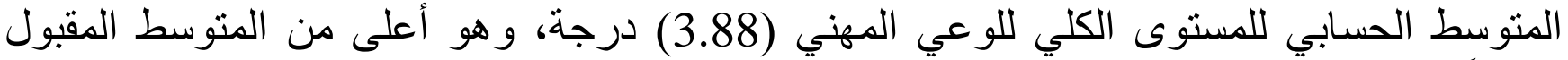

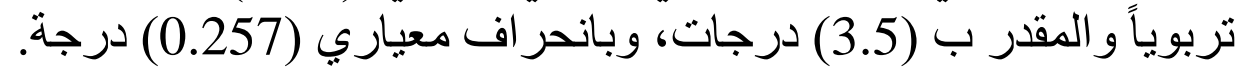

مستوى الوعي المهني لطلبة الصف الثاني عشر في كل مجال: المجال الأول: أنثطة التوجيه المهني: للكثف عن مستوى الوعي المهني في مجال " أنشطة التوجيه المهني" نم استخر اج المتوسطات 
الحسابية، و الانحر افات المعيارية لفقرات هذا المجال مرتبة تنازليا، وجدول (2) يبين ذلك.

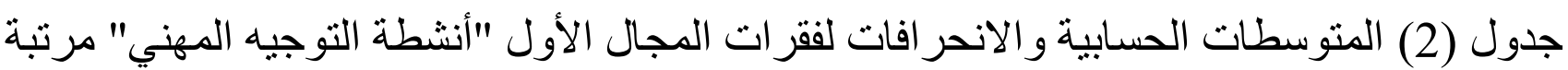
تناز ليا

\begin{tabular}{|c|c|c|c|}
\hline الانمعياري & الحستوسط & فقرات مجال أنشطة التوجيه المهني & 5 \\
\hline 1.003 & 4.11 & بها الطالبة التوجيه المهني مهمة في مختلف المر احل التعليمية التي يمر & 1 \\
\hline 0.853 & 3.95 & المدرورة تضمين أنشطة التوجيه المهني ضمن الفعاليات المنفذة داخل & 2 \\
\hline 0.969 & 3.94 & أجد في أنشطة التوجيه المهني ما يساعد الطلبة على اختيار المهنة & 3 \\
\hline 0.998 & 3.70 & المبكرة للطالب المه تقديم أنشطة التوجيه المهني في المر احل العمرية & 4 \\
\hline 0.946 & 3.64 & غإن تضدين أنشطة التوجيه المهني ضمن فعاليات وأنشطة المدرسة & 5 \\
\hline 1.181 & 3.47 & أرى أن تقتصر أنشطة التوجيه المهني على الصف العاثشر & 6 \\
\hline 1.036 & 3.42 & ألى أنشطة بصعوبة قدرة الطالب في اختيار المهنة المناسبة دون الرجوع & 7 \\
\hline 1.104 & 3.23 & إختيار المهامة المناسبة التوجيه المهني ضعيفة في مساعدة الطلبة على & 8 \\
\hline 1.005 & 3.22 & أفضل أن يقضي الطالب وقتا كبير ا في أنشطة التوجيه المهني & 9 \\
\hline 0.495 & 3.63 & 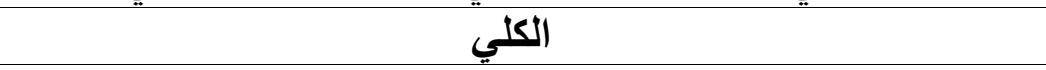 & \\
\hline
\end{tabular}

يبين جدول (2) أن الفقرة (1) و التي تتص على " أرى أن أنشطة التوجيه المهني مهمة في مختلف دئ

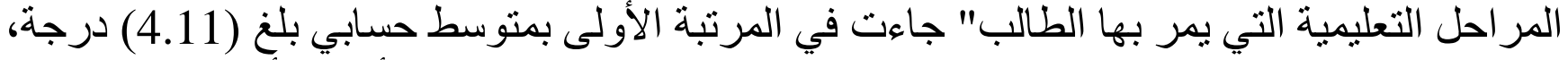

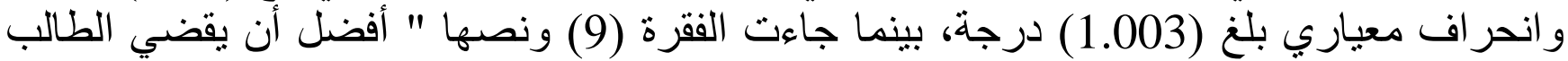

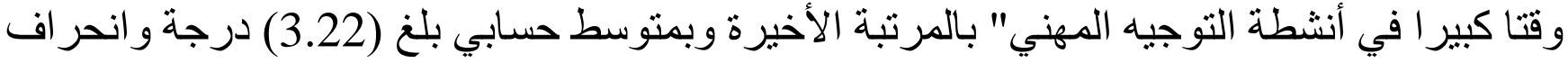
معياري بلغ (1.005) درجة.

\section{المجال الثاني: الاتجاه نحو العمل:}

للكثف عن مستوى الوعي المهني في مجال " الاتجاه نحو العمل " تم استخراج المتوسطات

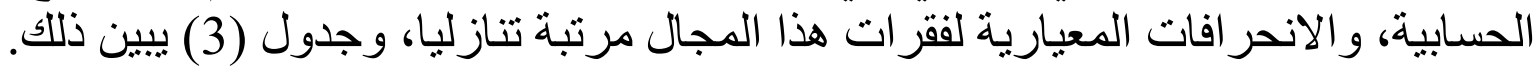

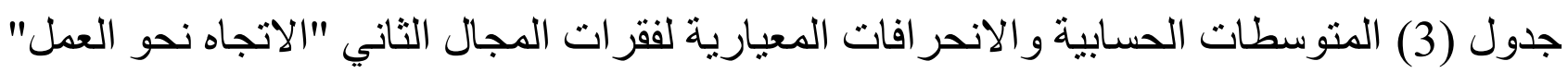
مرتبة تنازليا

\begin{tabular}{|c|c|}
\hline الاتحراف المعياري & المتوسط \\
\hline
\end{tabular}


IJASOS- International E-Journal of Advances in Social Sciences, Vol. VI, Issue 17, August 2020

\begin{tabular}{|c|c|c|c|}
\hline 0.344 & 4.87 & أرى أن العمل من العناصر الأساسية في حياة الفرد & 10 \\
\hline 0.763 & 4.40 & الاستثرار في العمل الفول عالم العمل له دور في تحقيق & 11 \\
\hline 0.878 & 4.36 & جميع المهن مهما كانت طبيعتها تستحق التقدير & 12 \\
\hline 0.664 & 4.35 & أشجع الفرد على تقبل وجهات النظر اتجاه المهن و أهميتها & 13 \\
\hline 1.198 & 3.58 & أجد العمل مهما اختلف متعب و غير مهتع & 14 \\
\hline 0.932 & 3.58 & من الضروري ألّا يطغى العائد المادي على طبيعة العمل. & 15 \\
\hline 1.094 & 3.22 & يعد العائد المادي للمهنة أكثر أهمية من طبيعة المهنة نفسها & 16 \\
\hline 0.500 & 4.05 & 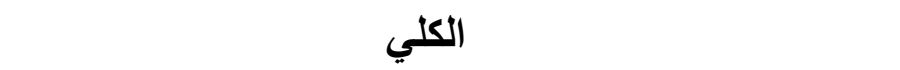 & \\
\hline
\end{tabular}

يبين جدول (3) أن الفقرة (10) والتي تنص على " أرى أن العمل من العناصر الأساسية في حياة

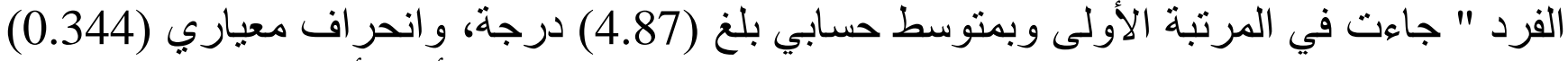

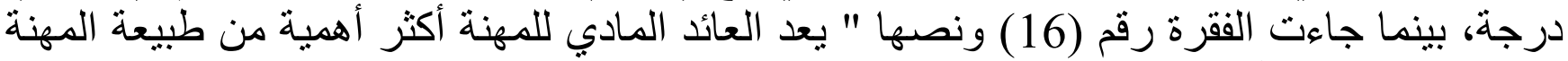

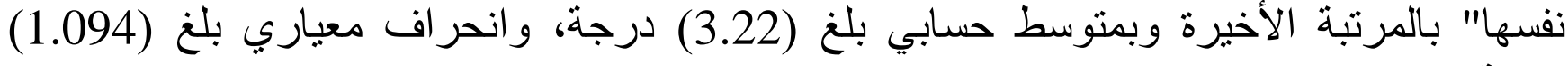
درجة.

المجال الثالث: تحديد الميول والقدرات المهنية

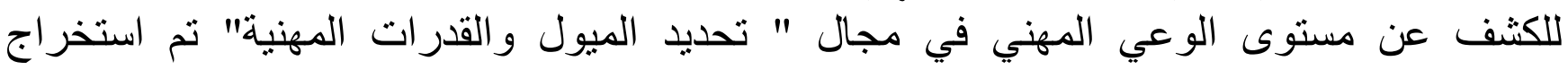
المتوسطات الحسابية، والانحر افات المعيارية لفقرات هذا المجال مرنبة تنازليا، والجدول (4) يبين ذلك.

جدول (4) المتوسطات الحسابية و الانحر افات المعيارية لفقرات المجال الثالث "تحديد الميول

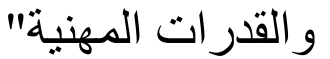

\begin{tabular}{|c|c|c|c|}
\hline الاتحر اف المعياري & 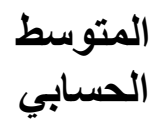 & فقرات مجال تحديد الميول والقدرات المهنية & b \\
\hline 0.625 & 4.54 & أقرار المهني & 17 \\
\hline 0.777 & 4.19 & بها أرى أنه من المهم أن يركز الفرد على المهن التي يستطيع القيام & 18 \\
\hline 0.958 & 4.03 & إن قدرة الفرد على القيام بعمل يتقلم على ميوله ور غبته اتجاه & 19 \\
\hline
\end{tabular}


IJASOS- International E-Journal of Advances in Social Sciences, Vol. VI, Issue 17, August 2020

\begin{tabular}{|c|c|c|c|}
\hline & & 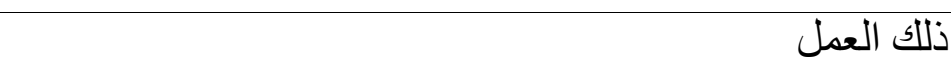 & \\
\hline 0.967 & 3.76 & أرى أن اتخاذ القرار المهني لا يستدعي ربطه بميول الفرد & 20 \\
\hline 1.113 & 3.45 & أفضل تجنب التفكير الطويل في مهن لا يستطيع الفرد القيام بها & 21 \\
\hline 1.131 & 3.21 & المناسب كثرة الخيار ات المهنية تعيق اتخاذ الفرد للقرار المهني & 22 \\
\hline 0.344 & 2.74 & يمكنتي القيام بجميع المهن مهما اختلفت متطلباتها & 23 \\
\hline 0.381 & 3.70 & الكلي & \\
\hline
\end{tabular}

يبين الجدول (4) أن الفقرة (17) و التي تتص على "أعتقد بضرورة معرفة متطلبات المهن المرغوبة

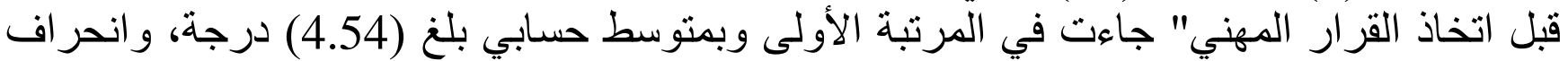

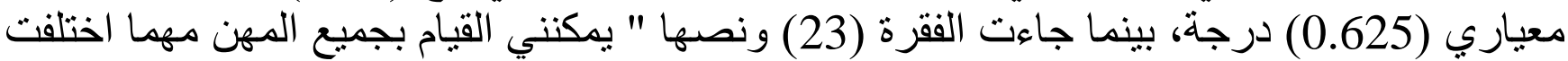
متطلباتها" بالمرنبة الأخيرة وبمتوسط حسابي بلغ (2.74) درجة، و انحر اف معياري بلغ (0.344) درجة.

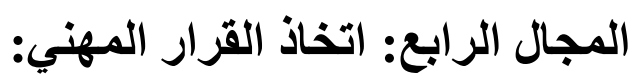

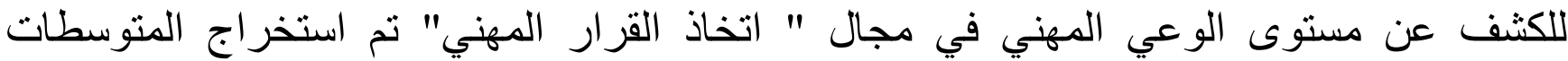
الحسابية، و الانحر افات المعيارية لفقرات هذا المجال مرتبة تنازليا، وجدول (5) يبين ذلك. جدول (5) المتوسطات الحسابية والانحر افات لفقرات المجال الرابع "اتخاذ القرار المهني" مرنبة ولية تناز ليا

\begin{tabular}{|c|c|c|c|}
\hline الانحر اف المعياري & 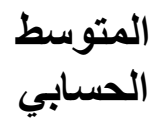 & فقرات مجال اتخاذ القرار المهني & b \\
\hline 0.949 & 4.26 & ذلك بنفسة أن يقوم الآخرون باختيار مهنة للفرد بدلا من أن يقوم & 24 \\
\hline 0.714 & 4.25 & أفضر أن بلتحق الفرد بمهن أخرى إن لم يحصل على المهنة & 25 \\
\hline 1.233 & 3.90 & باقي المهن الأخرى الخطأ أن يركز الفرد على مهنة واحدة ويغفل & 26 \\
\hline 0.935 & 3.82 & أرىى أن يقبل الفرد بأي مهنة أقل مما بطمح إليه في حالة تعذر & 27 \\
\hline
\end{tabular}




\section{IJASOS- International E-Journal of Advances in Social Sciences, Vol. VI, Issue 17, August 2020}

\begin{tabular}{|c|c|c|c|}
\hline 1.118 & 3.76 & أثنجع اعتماد الفرد على أصدقائه في الاختيار المهني & 28 \\
\hline 1.094 & 3.50 & إن تدخية مستقبلية الآباء في اختيار مهنة لأبنائهم يسبب حدوث مشاكل & 29 \\
\hline 1.172 & 3.46 & أعنق أن ابتعاد الفرد عن ممارسة المهن أفضل من أن يلتحق & 30 \\
\hline 1.194 & 3.11 & عن باقي المهن الأخركز الفرد اهتمامه على المهنة التي يريد ويبتعد & 31 \\
\hline 1.072 & 2.55 & المن الضروري لأبنائه أن يلعب الأب دورا رئيسيا في الاختيار & 32 \\
\hline 0.436 & 3.62 & الكلي & \\
\hline
\end{tabular}

يبين الجدول (5) أن الفقرة (24) و التي تتص على " يمكن أن يقوم الآخرون باختيار مهنة للفرد بدلا

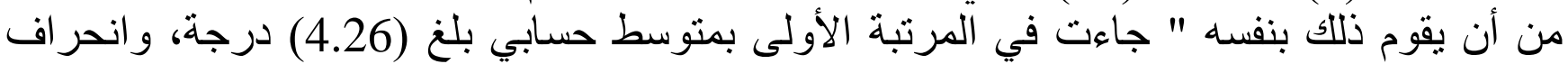

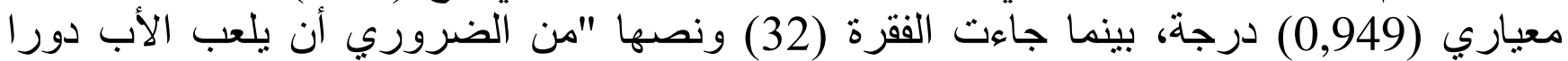

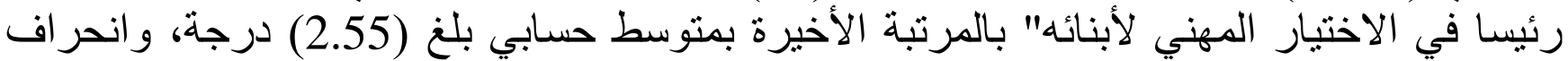
معياري بلغ (1.072) درجة.

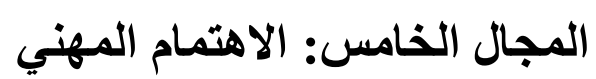
للكثف عن مستوى الوعي المهني في مجال "الاهتمام المهني" تم استخر اج المتوسطات الحسابية، و الانحر افات المعيارية لفقرات هذا المجال مرتبة تنازليا، وجدول (6) يبين ذللك.

جدول (6) المتوسطات الحسابية والانحر افات المعيارية لفقرات المجال الخامس "الاهتمام المهني" مرنبة تنازليا

\begin{tabular}{|c|c|c|c|}
\hline الانحر افت & المستوسط & فقرات الاهتمام المهني & $\hat{b}$ \\
\hline 0.637 & 4.72 & أعتقد بضرورة تحلي الفرد بالثقة بالنفس عند الاختيار المهني & 33 \\
\hline 0.587 & 4.67 & أشجع الفرد على امتلاك رؤية واضحة حول مهنة المستقبل & 34 \\
\hline 0.614 & 4.62 & أرى ضر ضرورة قيام الفرد بمعرفة كيفية الوصول إلى المهنة & 35 \\
\hline 0.763 & 4.40 & عملية الاختيار المهرد بمهنة مناسبة منذ المر احل العمرية المبكرة تسهل & 36 \\
\hline 0.983 & 4.10 & تحمل المسؤولية الاختيار المهني تقع على عاتق الفرد نفسه وقدرته على & 37 \\
\hline 1.041 & 3.98 & المهى الفرد تجنب النظرة السلبية اتجاه الاهتمام بعملية الاختيار & 38 \\
\hline
\end{tabular}


IJASOS- International E-Journal of Advances in Social Sciences, Vol. VI, Issue 17, August 2020

\begin{tabular}{|c|c|c|c|}
\hline 1.123 & 3.96 & أعتقد بعدم جدوى معرفة ارتباط المو اد الدر اسية بالمهن & 39 \\
\hline 1.091 & 3.66 & أنجع ابتعاد الفرد عن التفكير في أي مهنة في المر احل المبكرة & 40 \\
\hline 0.410 & 4.26 & الكلي & \\
\hline
\end{tabular}

يبين جدول (6) أن الفقرة (33) التي تتص على "أعتقد بضرورة تحلي الفرد بالثقة بالنفس عند

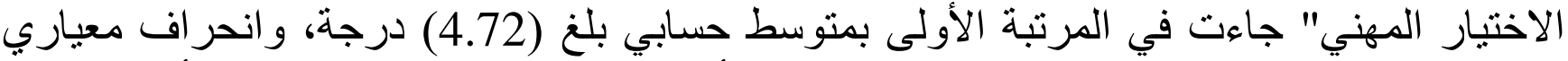

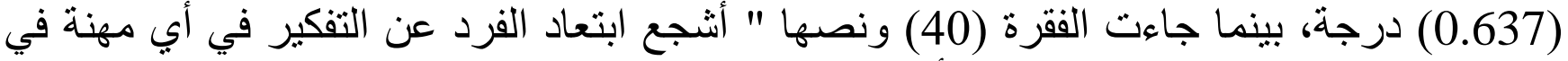

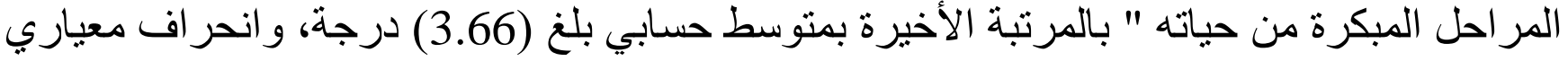
بلغ (1.091) درجة.

\section{المجال السادس: التخطيط المهني}

للكثف عن مستوى الوعي المهني في مجال " التخطيط المهني" تم استخر اج المتوسطات الحسابية،

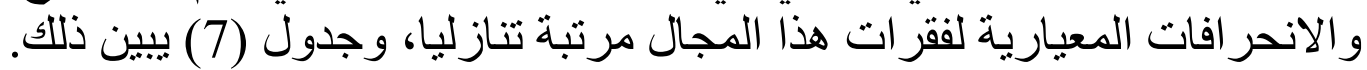

جدول (7) المتوسطات الحسابية و الانحر افات المعيارية لفقر ات المجال السادس "التخطيط المهني" وبني

مرنبة تنازليا

\begin{tabular}{|c|c|c|c|}
\hline المعياري & المتوسط الحسابي & فقرات مجال التخطيط المهني & م \\
\hline 0.633 & 4.56 & أعتقد أن جمع المعلومات حول المهن ومتطلباتها يسهم في الاختيار & 41 \\
\hline 0.671 & 4.48 & أثجع الفرد على التحديد الأولي للمهنة المرغوبة حتى يحدد مساره & 42 \\
\hline 0.867 & 4.25 & أرى أَنه لا حاجة لتحديد الأهداف المرتبطة بالتخطيط المهني للفرد & 43 \\
\hline 0.936 & 4.22 & جمع المعلومات عن المهن المختلفة يعتبر مضيعة للوقت & 44 \\
\hline 0.760 & 4.11 & السليم المارسة التجريبية تعد متطلبا مهما لعملية اتخاذ القرار المهني & 45 \\
\hline 1.055 & 3.76 & مهنة مستقبلا جدوى تحديد الأهداف المهنية طالما سيلتحق الفرد في & 46 \\
\hline 1.065 & 2.80 & أعنقا أن الممارسة التجريبية للمهن وحدها تكفي لاختيار المهنة & 47 \\
\hline 0.419 & 4.02 & الكلي & \\
\hline
\end{tabular}

يبين جدول (7) أن الفقرة (41) و التي تنص على " أعتقد أن جمع المعلومات حول المهن ومتطلباتها

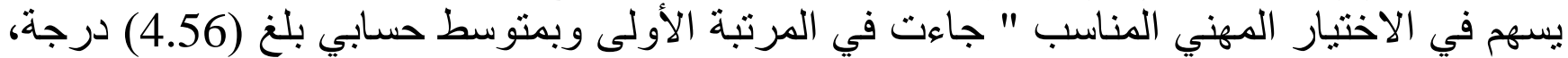
و انحر اف معياري بلغ (0.633) درجة، بينما جاءت الفقرة رقم (47) ونصها "أعتقد أن الممارسة الأنة

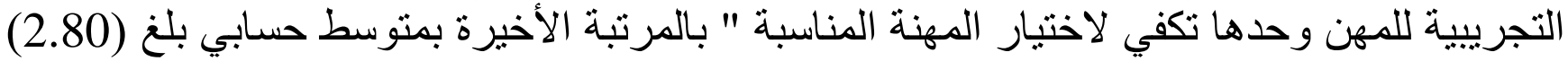

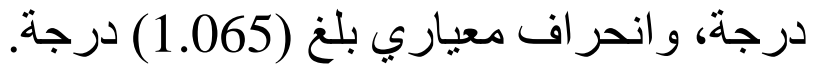


النتائج المتعلقة بالسؤال الثاني: ما مستوى الوعي المهني لاى آباء طلبة الصف الثاني عشر؟ مستوى الوعي المهني لاى آباء طلبة الصف الثاني عشر في جميع محاور الأداة:

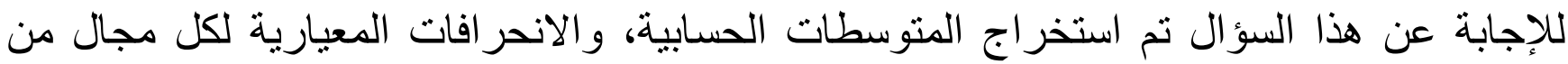

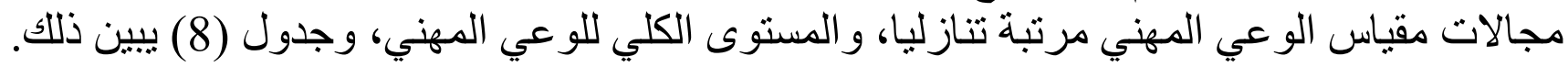
جدول (8) المتوسطات الحسابية والانحر افات المعيارية لكل مجال من مجالات مقياس الوعي المهني

\begin{tabular}{|c|c|c|c|}
\hline الالحيراف & المستوسطي & مجالات مقياس الوعي المهني & r \\
\hline 0.431 & 4.10 & الاهتمام المهني & 1 \\
\hline 0.391 & 4.01 & الاتجاه نحو العمل & 2 \\
\hline 0.446 & 3.90 & التخطيط المهني & 3 \\
\hline 0.361 & 3.62 & تحديد الميول و القدر ات المهنية & 4 \\
\hline 0.458 & 3.64 & أنشطة التوجيه المهني & 5 \\
\hline 0.465 & 3.54 & اتخاذ القرار المهني & 6 \\
\hline 0.275 & 3.80 & الكلي & \\
\hline
\end{tabular}

يبين جدول (8) أن مجال "الاهتمام المهني" جاء في المرتبة الأولى بأعلى متوسط حسابي بلغ

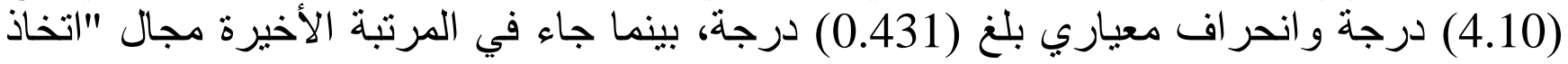

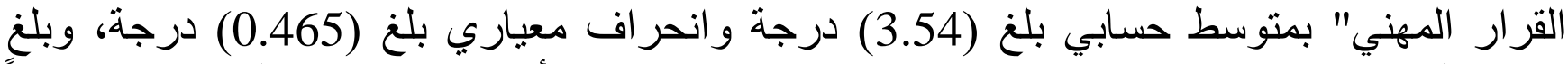
المتوسط الحسابي للمستوى الكلي للوعي المهني (3.80) وهو (3.

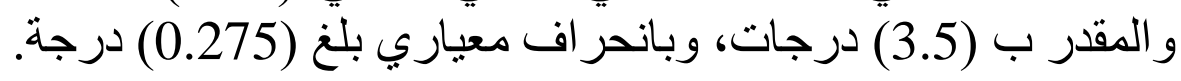
مستوى الوعي المهني لاى آباء طلبة الصف الثاني عشر في كل مجال:

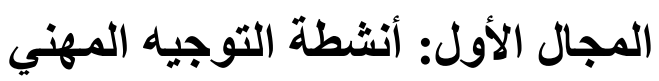
للكثف عن مستوى الوعي المهني في مجال " أنشطة التوجيه المهني" تم استخر اج المتوسطات

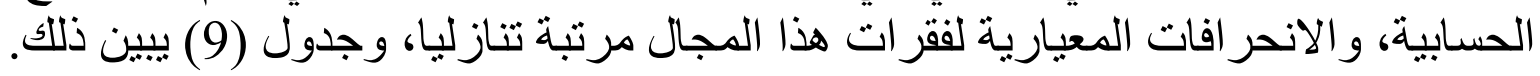
جدول (9) المتوسطات الحسابية و الانحر افات المعيارية للمجال الأول "أنشطة التوجيه المهني" مرتبة تنازليا

\begin{tabular}{|c|c|c|c|}
\hline 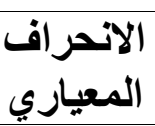 & المتوسط المبي & فقرات مجال أنشطة التوجيه المهني & م \\
\hline 0.906 & 4.11 & أرى أن أنشطة التوجيه المهني مهمة في مختلف المر احل التعليمية & 1 \\
\hline 0.885 & 3.96 & أجد في أنشطة التوجيه المهني ما يساعد الطلبة على اختيار المهنة & 2 \\
\hline 0.788 & 3.93 & أعتقد بضرورة تضمين أنشطة التوجيه المهني ضمن الفعاليات & 3 \\
\hline
\end{tabular}


IJASOS- International E-Journal of Advances in Social Sciences, Vol. VI, Issue 17, August 2020

\begin{tabular}{|c|c|c|}
\hline & & المنفذة داخل المدرسة \\
\hline 0.889 & 3.59 & أعتقدة أن تضمين أنشطة التوجيه المهني ضمن فعاليات و أنشطة \\
\hline 0.432 & 3.59 & إختيار إسهاماتة أنشطنة النتوجيه المهني ضعيفة في مساعدة الطلبة على \\
\hline 1.091 & 3.52 & أرى أن تقتصر أنشطة التوجيه المهني على الصف العاثر \\
\hline 1.051 & 3.47 & أرى أنه من غير المهر تقديم أنشطة التّوجيه المهني في المر احل \\
\hline 1.038 & 3.46 & أرجت بصع إلى أنشطة قدرة التوجياه المهيني اختيار المهنة المناسبة دون \\
\hline 1.050 & 3.22 & أفضل أَن يقضي الطالب وقتا كبير آ في أنشطة التوجيه المهني \\
\hline 0.458 & 3.64 & 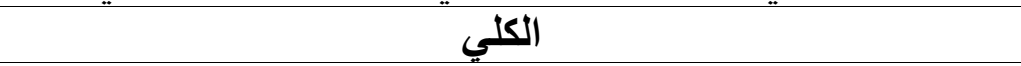 \\
\hline
\end{tabular}

يبين جدول (9) أن الفقرة (1) والتي تتص على " أرى أن أنشطة التوجيه المهني مهمة في مختلف دئ دئ

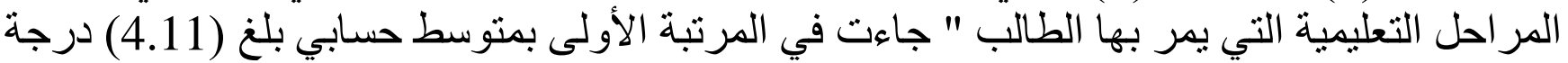

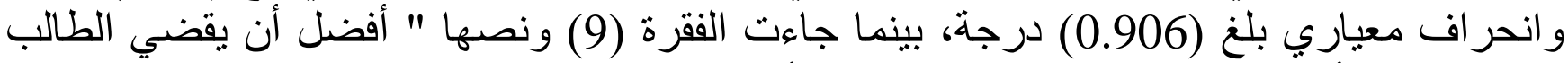

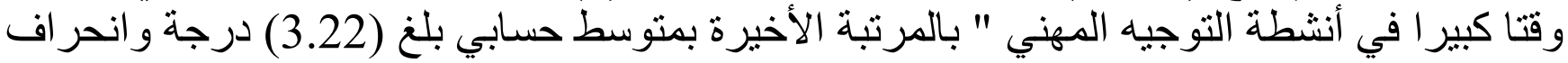
معياري بلغ (1.050) درجة. المجال الثاني: الاتجاه نحو العمل

للكثف عن مستوى الوعي المهني في مجال " الاتجاه نحو العمل " تم استخراج المتوسطات

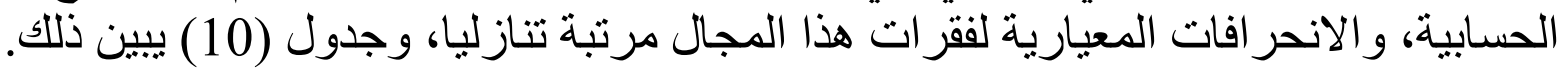
جدول (10) المتوسطات الحسايية والانحر افات المعيارية لفقرات المجال الثاني "الاتجاه نحو العمل" مرتبة تنازليا

\begin{tabular}{|c|c|c|c|}
\hline المعياري & الحستابي & فقرات مجال الاتجاه نحو العمل & ? \\
\hline 0.413 & 4.86 & أرى أن العمل من العناصر الأساسية في حياة الفرد & 10 \\
\hline 0.812 & 4.37 & جميع المهن مهما كانت طبيعتها تستحق التقدير & 11 \\
\hline 0.707 & 4.34 & إلعمل تشوق الفرد لاخول عالم العمل له دور في تحقيق الاستقر ار في & 12 \\
\hline 0.660 & 4.30 & أنشجع الفرد على تقبل وجهات النظر اتجاه المهن و أهميتها & 13 \\
\hline 1.232 & 3.51 & أجد العمل مهما اختلف متعب و غير ممتع & 14 \\
\hline 0.959 & 3.49 & من الضروري أن لا بطغى العائد المادي على طبيعة العمل. & 15 \\
\hline 1.040 & 3.26 & يعد العائد المادي للمهنة أكثر أهية من طبيعة المهنة نفسها & 16 \\
\hline 0.391 & 4.01 & الكلي & \\
\hline
\end{tabular}

يبين جدول (10) أن الفقرة (10) والتي تنص على " أرى أن العمل من العناصر الأساسية في حياة الفرد " جاءت في المرتبة الأولى بمنوسط حسابي بلغ (10.86) درجة ولني وانحر اف معياري بلغ (0.413) 
درجة، بينما جاءت الفقرة (16) ونصها " يعد العائد المادي للمهنة أكثر أهمية من طبيعة المهنة نفسها " بالمرتبة الأخيرة بمتوسط حسابي بلغ (3.26) درجة، و وانحر اف معياري بلغ (16) (1.040) درجة. المجال الثالث: تحديد الميول والقدرات المهنية للكثف عن مستوى الوعي المهني في مجال " تحديد الميول والقدرات المهنية" تم استخراج المتوسطات الحسابية، والانحر افات المعيارية لفقرات هذا المجال مرتبة تنازليا، وجدول (11) يبين ذللك.

جدول (11) المتوسطات الحسابية و الانحر افات المعيارية لفقرات المجال الثالث "تحديد الميول

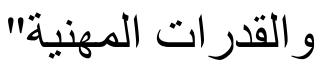

\begin{tabular}{|c|c|c|c|}
\hline المعياري & الحسابي & فقرات مجال تحديد الميول و القرات المهنية & r \\
\hline 0.743 & 4.32 & أعتنق بضرورة معرفة متطلبات المهن المر غوبة قبل اتخاذ القرار & 17 \\
\hline 0.770 & 07 & أرى أَنْه من المهم أن يركز الفرد على المهن التي يستطيع القيام بها & 18 \\
\hline 0.918 & 3.90 & العمل قدرة الفرد على القيام بعمل يتقام على ميوله ورغبته اتجاه ذلك & 19 \\
\hline & & أرى أن اتخاذ القرار المهني لا يستدعي ربطه بميول الفرد المهنية & 20 \\
\hline 05 & 8 & أفضل تجنب التفكير الطويل في مهن لا بستطيع الفرد القيام بها & 21 \\
\hline & 17 & إن كثرة الخيار ات المهنية تعيق اتخاذ الفرد للقرار المهني المناسد & 22 \\
\hline & 74 & يمكنني القيام بجميع المهن مهما اختلفت متطلباتها & 23 \\
\hline 0.36 & 62 & لكلي & \\
\hline
\end{tabular}

يبين جدول (11) أن الفقرة (17) و التي تتص على "أعتقد بضرورة معرفة متطلبات المهن المرغوبة

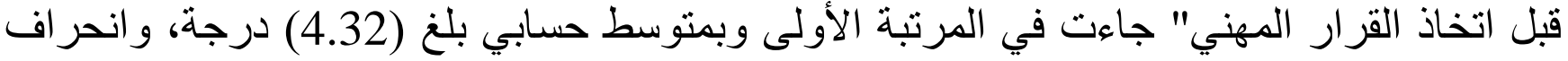

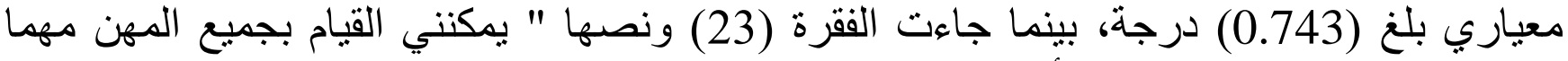
اختلفت متطلباتها " بالمرنبة الأخيرة بمتوسط حسابي بلغ (2.74) درجة، ورة وانحر اف معياري بلغ (1.023)

\section{المجال الرابع: التخاذ القرار المهني}

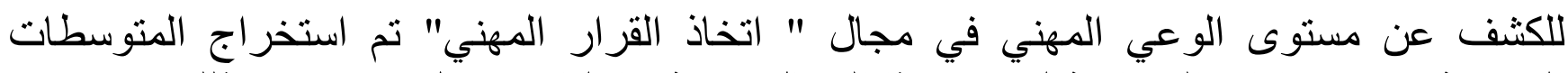
الحسابية، و الانحر افات المعيارية لفقر ات هذا المجال مرتبة تنازليا، وجدول (12) يبين ذللك. جدول (12) المتوسطات الحسابية والانحر افات المعيارية لفقرات المجال الر ابع "اتخاذ القرار

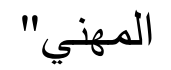

\begin{tabular}{|c|c|c|c|}
\hline الاتحراف & الحستوسط & فقرات مجال اتخاذ القرار المهني & ? \\
\hline 0.847 & 4.12 & أفر غو أن يلتحق الفرد بمهن أخرى إن لم يحصل على المهنة & 24 \\
\hline
\end{tabular}


IJASOS- International E-Journal of Advances in Social Sciences, Vol. VI, Issue 17, August 2020

\begin{tabular}{|c|c|c|c|}
\hline 1.040 & 4.05 & بنفكن أن يقوم الآخرون باختيار مهنة للفرد بدلا من أن يقوم ذلك & 25 \\
\hline 0.998 & 3.81 & أَرى أن يقبل الفرد بأي مهنة أقل مما يطمح إليه في حالة تعذر & 26 \\
\hline 1.048 & & أشُجع اعتماد الفرد على أصدقائه في الاختيار المهني & 27 \\
\hline 1.209 & 3.78 & أرى أنه من الخطاً أن يركز الفرد على مهنة واحدة ويغفل باقي & 28 \\
\hline 1.215 & 3.40 & إنق تدخل الآباء في اختيار مهنة لأبنائهم يسبب حدوث مشاكل مهنية & 29 \\
\hline 1.211 & 3.38 & إن ابتعاد الفرد عن ممارسة المهن أفضل من أن يلتحق بمهن غير & 30 \\
\hline 1. & 3. & أفضل أن يركز الفرد اهتمامه على المهنة التي يريد ويبتعد عن باقي & 31 \\
\hline 1.122 & 2 & لأبنائه الضروري أن يلعب الأب دور ا رئيسيا في الاختيار المهني & 32 \\
\hline 0.465 & 3.54 & 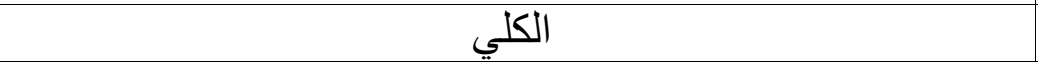 & \\
\hline
\end{tabular}

يبين جدول (12) أن الفقرة (24) و التي تتص على " أفضل أن يلتحق الفرد بمهن أخرى إن لم يحصل

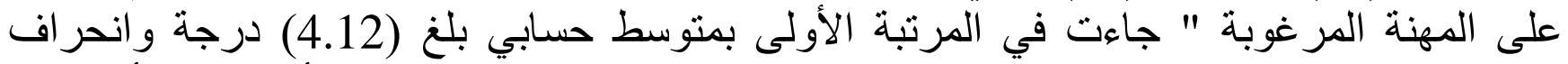

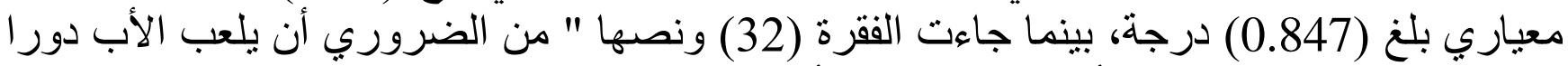

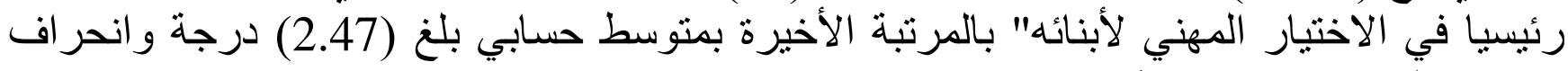
معياري بلّغ (1.122) درجية.

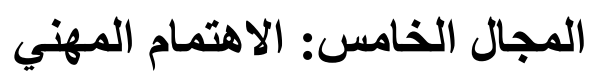
للكثف عن مستوى الوعي المهني في مجال "الاهتمام المهني" تم استخر اج المتوسطات الحسابية، و الانحر افات المعيارية لفقرات هذا المجال مرنبة تنازليا، وجدول (13) يبين ذلانك. جدول (13) المتوسطات الحسابية و الانحر افات المعيارية لفقرات المجال الخامس "الاهتمام المهني" مرتبة تنازليا

\begin{tabular}{|c|c|c|c|}
\hline الانحر اف المياري & المتوسط المبي & 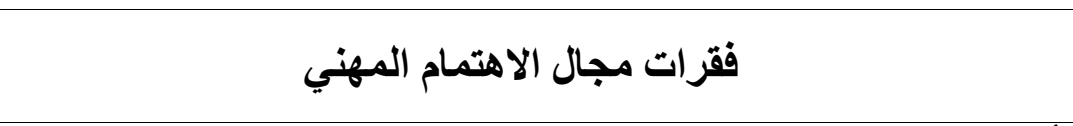 & r \\
\hline 0.675 & 4.58 & أشجع الفرد على امتلاك رؤية و اضحة حول مهنة المستقبل & 33 \\
\hline 0.700 & 4.57 & أعتقد بضرورة تحلي الفرد بالثقة بالنفس عند الاختيار المهني & 34 \\
\hline 0.661 & 4.42 & أرى ضرورة قيام القرد بمعرفة كيفية الوصول إلى المهنة المر غوبة & 35 \\
\hline 0.837 & 4.20 & إن تفكير الفرد بمهنة مناسبة منذ المر احل العمرية المبكرة تسهل عملية & 36 \\
\hline
\end{tabular}


IJASOS- International E-Journal of Advances in Social Sciences, Vol. VI, Issue 17, August 2020

\begin{tabular}{|c|c|c|c|}
\hline 0.969 & 4.09 & إلن عمولية الاختيار المهني تقع على عاتق الفرد نفسه وقدرته على تحمل & 37 \\
\hline 0.990 & 3.85 & على الفرد تجنب النظرة السلبية تجاه الاهتمام بعملية الاختبار المهني & 38 \\
\hline 1.073 & 3.70 & أعتقد بعدم جدوى معرفة ارتباط المواد الدر اسية بالمهن المر غوبة & 39 \\
\hline 1.115 & 3.43 & حياته أنتعاد الفرد عن التفكير في أي مهنة في المر احل المبكرة من & 40 \\
\hline 0.431 & 4.10 & (الكلي & \\
\hline
\end{tabular}

يبين الجدول (13) أن الفقرة (33) التي تتص على "أنجع الفرد على امتلاك رؤية واضحة حول

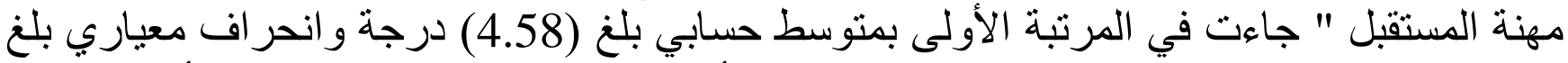

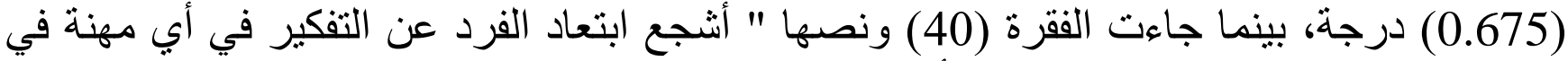

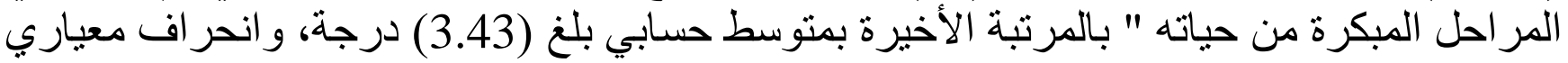
بلغ (1.115) درجة.

\section{المجال السادس: التخطيط المهني (1الهي}

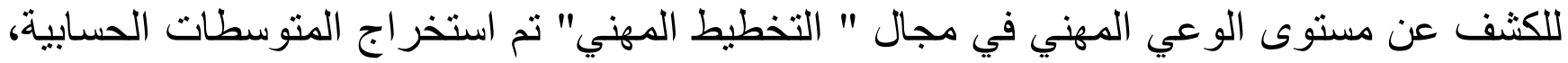

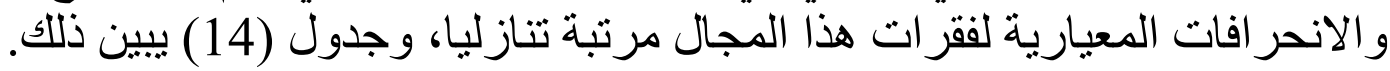

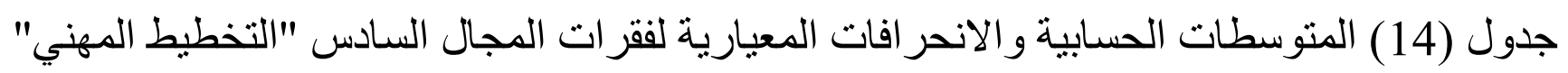
مرتبة تناز ليا

\begin{tabular}{|c|c|c|c|}
\hline المعياري & 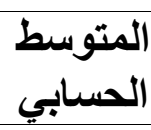 & فقرات مجال التخطيط المهني & P \\
\hline 0.675 & 4.48 & أمهنقي ألن جمع المعلومات حول المهن ومنطلباتها يسهم في الاختيار & 41 \\
\hline 0.715 & 4.27 & ألمهنج الفرد على التحديد الأولي للمهنة المر غوبة حتى يحدد مساره & 42 \\
\hline 0.893 & 4.13 & أرى أنّه لا حاجة لتحديد الأهداف المرتبطة بالتخطيط المهني للفرد & 43 \\
\hline 0.767 & 4.08 & السليم سارسة النجرييية تعد متطلبا مهما لعملية اتخاذ القرار المهني & 44 \\
\hline 1.039 & 3.93 & جمع المعلومات عن المهن المختلفة يعتبر مضيعة للوقت & 45 \\
\hline 1.021 & 3.68 & مهنة مستقبلا جدوى تحديد الأهداف المهنية طالما سيلتحق الفرد في & 46 \\
\hline 1.112 & 2.77 & ألمناستة أن الممارسة التجريبية للمهن وحدها تكفي لاختيار المهنة & 47 \\
\hline 0.446 & 3.90 & الكلي & \\
\hline
\end{tabular}

يبين جدول (14) أن الفقرة (41) و التي تنص على " أعتقد أن جمع المعلومات حول المهن ومتطلباتها

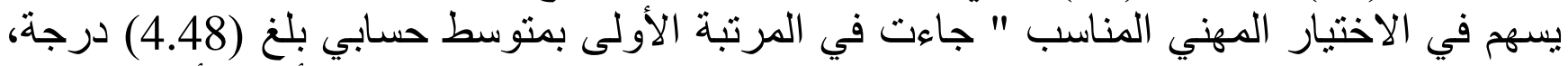
وانحراف معياري بلغ (0.675) درجة، بينما جاءت الفقرة (47) ونصها " العنقا لقد أن الممارسة 
التجريبية للمهن وحدها تكفي لاختبار المهنة المناسبة " بالمرتبة الأخيرة بمتوسط حسابي بلغ (2.77) درجة و انحر اف معياري بلغ (1.112) درجية.

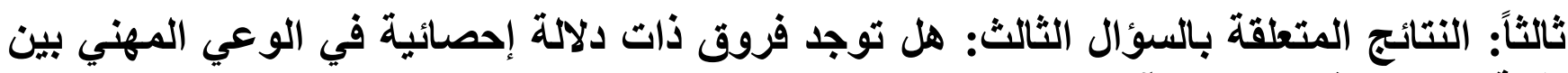

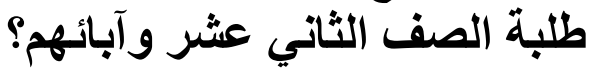

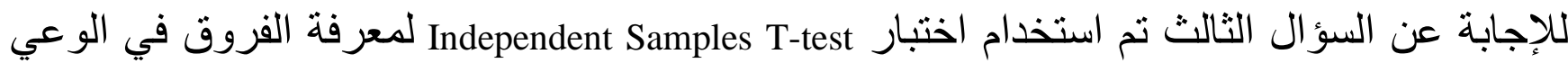
المهني بين طلبة الصف الثاني عشر و آبائهم، وكذلك لكل مجال من مجالات الوعي المهني، وجدول (15) يبين ذلك.

جدول (15) المتوسط الحسابي و الانحر اف المعياري وقيمة (T) لكل مجال من مجالات الوعي المهني وكليا

\begin{tabular}{|c|c|c|c|c|c|c|}
\hline مستوى الدلالة & قيمة & الالحريافي & الحسابي & العدد & العينة & المجال \\
\hline \multirow{2}{*}{0.615} & \multirow{2}{*}{0.504} & 0.495 & 3.63 & 312 & طلبة الصف الثاني & \multirow{2}{*}{ المهني } \\
\hline & & 0.458 & 3.64 & 312 & الآباء & \\
\hline \multirow{2}{*}{0.297} & \multirow{2}{*}{1.044} & 0.500 & 4.05 & 312 & طلبة الصف الثاني & \multirow{2}{*}{ العمل الاتجاه نحو } \\
\hline & & 0.391 & 4.01 & 312 & الآباء & \\
\hline \multirow{2}{*}{0.010} & \multirow{2}{*}{2.571} & 0.381 & 3.70 & 312 & طلبة الصف الثاني & \multirow{2}{*}{ و القدر ات المهنيد الميول } \\
\hline & & 0.361 & 3.62 & 312 & الآباء & \\
\hline \multirow[t]{2}{*}{0.043} & \multirow[t]{2}{*}{2.029} & 0.436 & 3.62 & 312 & طلبة الصف الثاني & \multirow{2}{*}{ اتخاذ القرار المهني } \\
\hline & & 0.465 & 3.54 & 312 & الآباء & \\
\hline \multirow[t]{2}{*}{0.000} & \multirow[t]{2}{*}{4.749} & 0.410 & 4.26 & 312 & طلبة الصف لثاني & \multirow[t]{2}{*}{ الاهتمام المهني } \\
\hline & & 0.431 & 4.10 & 312 & الآباء & \\
\hline \multirow[t]{2}{*}{0.001} & \multirow[t]{2}{*}{3.499} & 0.419 & 4.02 & 312 & طلبة الصف الثاني & \multirow[t]{2}{*}{ التخطيط المهني } \\
\hline & & 0.446 & 3.90 & 312 & الآباء & \\
\hline \multirow{2}{*}{0.001} & \multirow{2}{*}{3.474} & 0.257 & 3.88 & 312 & الطلبة & \multirow{2}{*}{ الكلي } \\
\hline & & 0.275 & 3.80 & 312 & الآباء & \\
\hline
\end{tabular}

يلحظ من جدول (15) وجود فروق ذات دلالة إحصائية في الوعي المهني بين طلبة الصف الثاءئي

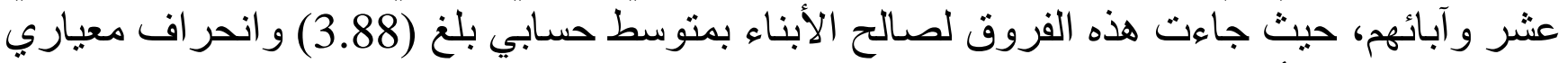

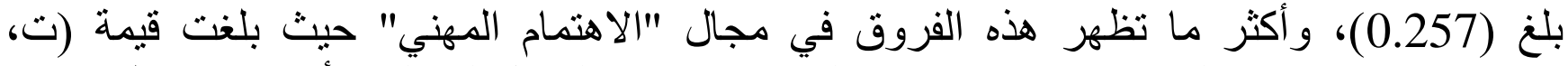

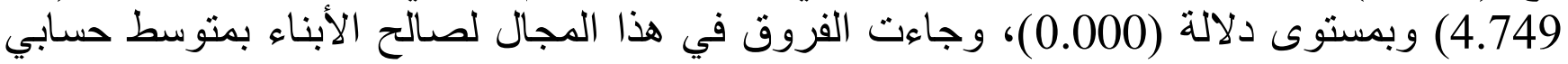
بلغ (4.26) وبانحر اف معيار دي بلغ (0.410). \begin{tabular}{l|l} 
http://ijasos.ocerintjournals.org & 894
\end{tabular} 
إن الآباء الذين درسو ا في النظام التعليمي بالمدارس، لم يتلقو ا مثل هذا الاهتمام لأن الأنشطة و البرامج إنج

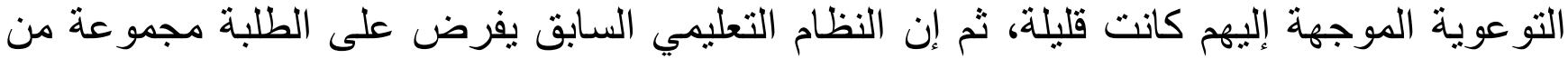

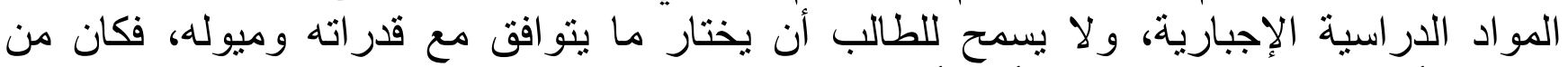
الطبيعي أن تكون الفروق لصالح الأبناء أكثر من الآباء.

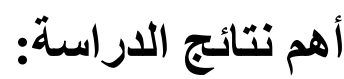
أ. جاء مستوى الوعي المهني بشكل عام أعلى من المستوى المقبول تربويـاً لمستوى الوعي المهني بالنسبة لطلبة الصف ألثاني عثر وكذلك بأل بالنسبة لآبائهم.

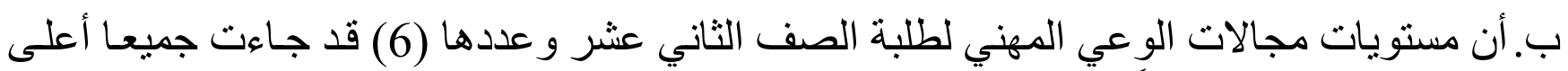
من المستوى المقبول نربوياً وكذلك بالالنسبة للآباء. ت.وجود فروق ذات دلالـة إحصـائية في الوعي المهني بشكل عـام لدى طلبة الصـف الثاني عشـر و آبائهم ولصالح طلبة الصف دون دلثاني عشر.

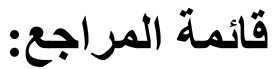

الحوارنة، إياد نايف (2005). أثر نمط التنشئة الأسرية في النضج المهني لدى طلبة الأول الثانوي في محافظة الكرك. رسالة ماجستير غير منشورة، جامعة مؤتة، الأردن. الثرعة، حسين سالم (2000)، الأمن النفسي وعلاقته بوضوح الهوية المهنية، مؤتة للار اسات

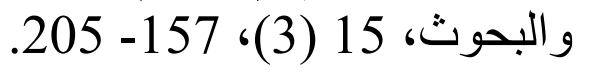

قطامي، نايفة (2007). نمو التفكير المهني للطفل (برنامج تدريب مهني). عمان، دار المسيرة. كريقر، ليندا سلفرمان (2005). إرشاد المو هوبين و المتفوقين. (ترجمة: سعيد حسني العزة)، عمان، دار الثقافة.

الغافري، سليمان بن علي (2005). النضه المهني لدى طلبة الصف العاثر بمنطقة الباطنة بسلطنة

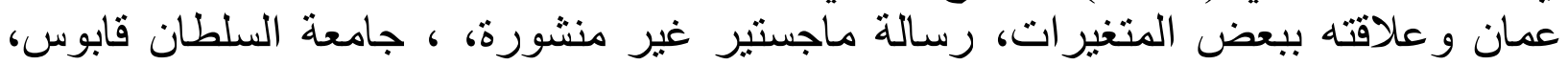
سلطنة عمان.

ملحم، سامي تحمد (2007). مبادئ التوجيه و الإرشاد النفسي. عمان: دار المسيرة. زهر ان، حامد عبد السلام (2002). التوجيه و الإرشاد النفسي. ط3، القاهرة: عالم الكتب.

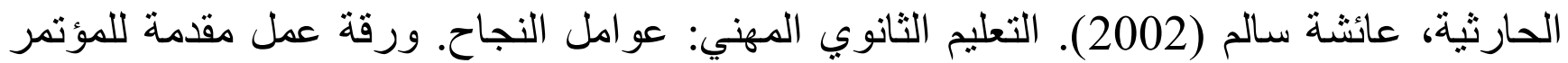

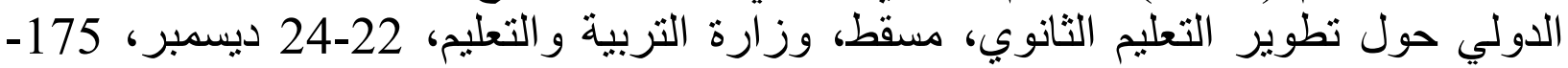
.190

\section{ARABIC REFERENCES IN ROMAN ALPHABETS}

Alhawarnat, 'liad Nayif (2005). 'Athar Namat Altanshiat Al'asriat fi Alnadj Almahnii Ladaa Tlbt Al'awal Althaanawii 
fi Muhafazat Alkark. Risalat Majstayr Ghyr Manshurat, Jamieatan Mutat, Al'urdunn.

Alshareatu, Husayn Salim (2000), Al'amn Alnafsiu Waealaqatuh Biwuduh Alhuiat Almahniati, Mutatan Lildirasat Walbihwith, 15 (3), 157- 205.

Qitami, Nayifa (2007). Numuin Altafkir Almahinia Liltafl (Branamij Tadrib Mahnia). Eumaan, Dar Almasirat.

Karayqr, Lynda Salafiruman (2005). 'lirshad Almawhubin Walmutfawiqin. (Trajmat: Saeid Husni Aleuzat), Eumaan, Dar Althaqafat.

Alghafri, Sulayman Bin Eali (2005). Alnadj Almahniu Ladaa Tlbt Alsafi Aleashir Bimintaqat Albatinat Bisiltanat Eamman Waealaqatih Bibaed Almutaghayirati, Risalat Majsatayr Ghyr Manshurat, , Jamieat Alsultan Qabaws, Saltanat Eaman

Mulhim, Sami Muhamad (2007). Mabadi Altawjih Wal'iirshad Alnafsi. Eamana: Dar Almasirat.

Zahran, Hamid Eabd Alsalam (2002). Altawjih Wal'iirshad Alnafsi. Ta3, Alqahirat: Ealam Alkutb.

Alharthiat, Eayishat Salim (2002). Altaelim Althaanawi Almahny: Eawamil Alnajah. Waraqat Eamal Muqadimat Lilmutamar Alduwalii Hawl Tatwir Altaelim Althaanawii, Masqati, Wizarat Altarbiat Waltaelim, 22-24 Disimbir, 175-190.

\section{REFERENCES}

Janet, U (2005). Parent/Guardian visualization of career and academic future of seventh graders enrolled in lowachieving schools, the career development quarterly, march 2005, volume 53, p 234- 245.

Lynda, A. S (1980). Career awareness of Grade nine girls: evaluation of treatment programs. unpublished doctoral dissertation of philosophy, university of Toronto. Canada. 